\title{
ARTIKELEN
}

\section{Tijd voor een Wet maatregelen virusuitbraak?}

\section{Over grondslagen voor afdwingbare gedragsvoorschriften}

\author{
M.A.D.W. de Jong
}

\section{Inleiding}

Het afgelopen jaar liet zien dat de overheid voor de bestrijding van COVID-19 soms haar toevlucht moest nemen tot controversiële regelgeving, vervolgens met veel moeite pas in november 2020 de toegezegde tijdelijke wet door het parlement kreeg en nog geen twee maanden later weer naarstig zocht naar een grondslag voor de avondklok. De Tijdelijke wet maatregelen covid-19 (Twm covid-19), de naam zegt het al, is een tijdelijke regeling. Deskundigen geven echter aan dat nieuwe virusuitbraken en nieuwe varianten van de ziekte in de toekomst zeker zullen opduiken. ${ }^{1}$ Het is daarom nuttig en nodig om te bezien welke lessen uit het afgelopen jaar getrokken kunnen worden en wat dit uit wetgevingsoogpunt betekent. Zoals de rijksoverheid mij in Postbus 51-spotjes voorhield toen ik afstudeerde: 'Een slimme meid is op haar toekomst voorbereid.' We mogen van de wetgever hetzelfde verwachten.

Onderwerp van deze bijdrage is allereerst een analyse van de grondslagen van de afdwingbare ${ }^{2}$ maatregelen die de Nederlandse overheid koos voor de maatregelen die het dagelijkse leven van burgers raken. ${ }^{3}$ Er zijn daarbij grofweg twee fasen te onderscheiden. Ten eerste de periode van half maart tot december 2020. De bedoelde gedragsvoorschriften werden toen opgenomen in noodverordeningen. Ik schets hun wettelijke basis en inhoud (par. 2) en ga in paragraaf 3 in op de belangrijkste bezwaren van de covidnoodverordeningen. Op 1 december trad een nieuw (tijdelijk) hoofdstuk van de Wet publieke gezondheid (Wpg) in werking. ${ }^{4} \mathrm{Op}$ basis daarvan werd een zeer uitgebreide ministeriële regeling vastgesteld, die allerlei za-

1 R. van den Brink, 'Wetenschappers: coronavirus gaat niet meer weg', https://nos.nl/ artikel/2370489-wetenschappers-coronavirus-gaat-niet-meer-weg.

2 M.b.t. thuiswerken en voor met name gedragsregels in de woningen en gebedshuizen gaf het kabinet 'dringende adviezen' betreffende aantallen bezoekers, hygiëne- en andere gedragsvoorschriften. Deze blijven hier verder vrijwel onbesproken. Zie daarvoor o.m. A.C. Hendriks, 'Nood breekt wet in tijden van corona', NJB 2020/14, p. 948-955 en J. Vleugel, 'Coronamaatregelen en godsdienstige bijeenkomsten?', NJB 2021/574, p. 594-600.

3 Buiten beschouwing blijft de meer specifieke wetgeving voor cruciale processen, zoals rechtspleging, verkiezingen en steunverlening aan bedrijven.

4 Wet van 28 oktober 2020, houdende Tijdelijke bepalingen in verband met maatregelen ter bestrijding van de epidemie van covid-19 voor de langere termijn (Tijdelijke wet maatregelen covid-19), Stb. 2020, 441. Zie daarover Kamerstuk 35526. 
ken regelde die voorheen in de noodverordeningen stonden. ${ }^{5}$ Ik schets ook deze aanpak in hoofdlijnen en bezie in hoeverre de problemen uit de eerste fase hiermee zijn opgelost (par. 4). Bij de bespreking richt ik me op de volgende aspecten van de coronamaatregelen: het territoriale bereik van de regelingen, de al dan niet genoegzame grondslag van bevoegdheden, in het bijzonder ten aanzien van grondrechten in de Grondwet $(\mathrm{Gw})$, en tot slot de mogelijkheden van bestuurlijke en democratische controle. Deze selectie is gemaakt omdat, zoals hieronder zal blijken, zich daar de meest klemmende juridische problemen voordoen. Ik sluit deze bijdrage af met een paragraaf waarin ik een aantal conclusies trek en aandachtspunten formuleer voor de opvolger van de Wet tijdelijke maatregelen covid-19 (par. 5).

\section{De eerste periode: aanwijzingen en noodverordeningen}

Bestrijding van infectieziekten wordt primair door de Wpg geregeld. ${ }^{6}$ De Wpg maakt een onderscheid tussen ziekten van de A-, B1-, B2- en C-categorie. Betreft het een infectieziekte van de B- of C-categorie, dan heeft in beginsel de burgemeester een belangrijke taak bij de bestrijding ervan. ${ }^{7}$ Het novel coronavirus werd eind januari 2020 echter als een virus van de zwaarste categorie (groep A) aangewezen, ofwel een virus dat een ernstige bedreiging vormt voor de volksgezondheid. ${ }^{8}$ Daarmee kreeg de Minister van Volksgezondheid, Welzijn en Sport (VWS) de leiding over de virusbestrijding, bijgestaan door met name de voorzitters van de veiligheidsregio's (art. 6, tweede en vierde lid, en 7 e.v. Wpg). ${ }^{9}$ De Wpg bevatte op dat moment vooral regelingen om individuele gevallen van (dreigende) besmettingen aan te pakken ${ }^{10}$ en de mogelijkheid om maatregelen te nemen gericht op gebouwen en vervoersmiddelen. ${ }^{11}$ In maart 2020 werd echter vrijwel meteen duidelijk, mede door eerdere ervaringen in Italië, dat een efficiënte aanpak van de virusuitbraak zich hiertoe niet kon beperken. Algemeen geldende gedragsvoorschriften voor vrijwel de gehele bevolking waren nodig. Op dat punt voorzag de Wpg niet in regelgevende bevoegdheid voor de Minister van VWS, ${ }^{12}$ maar in een systeem waarbij deze

5 Regeling van de Ministers van VWS, van JenV en van BZK van 19 november 2020, kenmerk 1784401-214492-WJZ, houdende tijdelijke bepalingen voor het Europese deel van Nederland in verband met maatregelen ter bestrijding van de epidemie van covid-19 (Tijdelijke regeling maatregelen covid-19), Stcrt. 2020, 62301.

6 Zie voor een bespreking van de achtergrond en totstandkoming van deze wet de bijdrage van Cammelbeeck in dit themanummer. Hij gaat tevens uitgebreid in op de reikwijdte van art. 7 Wpg, de samenhang met art. 39 Wvr en op bevoegdheden van de voorzitter van de veiligheidsregio.

$7 \quad$ Art. 6, derde lid, 7, tweede lid, en $10 \mathrm{Wpg}$.

8 Art. 20 jo. art. 1, sub e, Wpg. Regeling van de Minister voor Medische Zorg van 28 januari 2020, Regeling 2019-nCov, Stcrt. 2020, 6800.

9 Zie over deze eerste periode ook en deels uitgebreider Hendriks 2020; B.J.P.G. Roozendaal \& A.L. van de Sande, 'COVID-19 in het publiekrecht - een overzicht', NJB 2020/14, p. 938-947; J. Vink, 'Het Nederlandse staatsnoodrecht. Wat te doen met de EHBO-trommel die niet op orde is?', NJB 2020/18, p. 1308-1316 en Afdeling advisering Raad van State (RvS), 'Voorlichting over grondwettelijke aspecten van (voor)genomen crisismaatregelen', W04.20.0139/I/Vo, d.d. 25 mei 2020, te raadplegen op www.raadvanstate.nl.

10 Bijv. door een meldingsplicht voor artsen en een isolatieplicht voor individuen (art. 21-46 Wpg).

11 Art. 47 e.v. Wpg.

12 Art. 53 Wpg. 
via aanwijzingen de voorzitters van veiligheidsregio's de opdracht geeft om de hun toekomende bevoegdheden op het terrein van publieke gezondheid en openbare orde en veiligheid te gebruiken. ${ }^{13}$ Door vervolgens artikel 6, vierde lid, Wpg te koppelen met artikel 39 van de Wet veiligheidsregio's (Wvr) kregen de voorzitters van de veiligheidsregio de gemeentelijke noodverordeningsbevoegdheid van artikel 176 Gemeentewet (Gemw) ${ }^{14} \mathrm{Zij}$ oefenden vervolgens ter bestrijding van de covidcrisis bij uitsluiting van de burgemeesters uit de veiligheidsregio, die bevoegdheid bijna negen maanden uit. $^{15}$

Met een noodverordening mag van geldende regelgeving worden afgeweken, echter niet van de Grondwet en hoger internationaal recht (art. 176, eerste lid, Gemw). De gedragsvoorschriften in de covidnoodverordeningen waren, zoals ik hieronder verder bespreek, bijzonder ingrijpend: het normale sociale en economische verkeer kwam in sommige opzichten bijna tot stilstand. Dat veroorzaakte discussie over de vraag of de maatregelen rechtmatig waren en wie voor wat verantwoordelijk was. Dat was niet echt transparant geregeld. De noodverordeningsbevoegdheid lag in de periode van maart tot december 2020 dan wel bij de voorzitter van de veiligheidsregio, de inhoud van de noodverordeningen werd echter al snel vrijwel volledig gedicteerd door de minister, getuige de steeds gedetailleerdere ministeriële aanwijzingen. ${ }^{16}$ Voordat de minister een aanwijzing gaf, was er overleg binnen het kabinet, ${ }^{17}$ dat zich daarbij liet adviseren door de medische specialisten van het Outbreak Management Team (OMT) ${ }^{18}$ Voorts werd over de voorgenomen aanwijzingen overleg gevoerd in het Veiligheidsberaad, bestaande uit de 25 voorzitters van de veiligheidsregio's. ${ }^{19}$ Dit Veiligheidsberaad zette vervolgens, daarbij onder meer ondersteund door juristen van het ministerie, de aanwijzingen om in een mo-

13 Art. 7 jo. art. 6, vierde lid, e.v. Wpg.

14 Ook vrijwel alle andere openbare-ordebevoegdheden van de burgemeester uit de Gemw en de Wom werden ten behoeve van de virusbestrijding uitsluitend door de voorzitters van de veiligheidsregio's uitgeoefend (art. 39 Wvr).

15 De Wvr bevat in art. 53 ook een mogelijkheid om openbare-ordebevoegdheden van de burgemeester uit te laten oefenen door de Minister van Justitie en Veiligheid (JenV), maar van deze mogelijkheid is geen gebruik gemaakt. Zie daarover de kritische analyse van Cammelbeeck in dit themanummer.

16 Vgl. bijv. de eerste meer globale aanwijzingen van 15 maart 2020 met die van 26 juni en 14 oktober 2020, zie daarvoor www.rijksoverheid.nl/documenten?trefwoord=coronavirus\&startdatum= \&einddatum=\&onderdeel=Alle+ministeries\&type=Alle+documentenksoverheid.nl, en zoek op 'aanwijzing maatregelen COVID-19'.

17 Preciezer gezegd neemt de MCCb (Ministeriële Commissie Crisisbeheersing), waarvan de premier voorzitter is, de besluiten over het gehele maatregelenpakket. De premier, heeft in overeenstemming met de ministerraad deze commissie ingesteld: zie voor het instellingsbesluit: https:// wetten.overheid.nl/jci1.3:c:BWBR0038503\&z=2016-09-13\&g=2016-09-13. Zie voor de precieze crisisstructuur die bij de aanpak van de covidcrisis is opgezet: Kamerstukken II 2019/20, 30821, nr. 107 met bijlage en voor de overlegstructuur tussen de ministers en de veiligheidsregio's m.n. art. 7, eerste en vierde lid, en 44, eerste en tweede lid, Wvr. Uitgebreider: voorlichting van de Afdeling advisering RvS van 25 mei 2020, W04.20.0139/1/Vo, par. 3.

18 Art. 6c, eerste lid, Wpg. Het OMT maakt deel uit van het Rijksinstituut voor Volksgezondheid en Milieu (RIVM), zie www.rivm.nl/coronavirus-covid-19/omt\#OMT-leden.

19 De precieze rol van het Veiligheidsberaad komt elders in dit themanummer uitgebreid aan bod in de bijdrage van Becker en Geertjes. 
del-noodverordening. Deze diende als blauwdruk voor de noodverordening die door elke individuele voorzitter van de veiligheidsregio werd afgekondigd. ${ }^{20}$

Om welke voorschriften ging het? Gedurende de negen maanden dat de noodverordeningen van kracht waren, was er regionaal enige differentiatie, bijvoorbeeld ten aanzien van markten, verblijf in recreatiewoningen ${ }^{21}$ en mondkapjesplicht. ${ }^{22}$ Het overgrote deel van de gedragsvoorschriften werd echter in alle regio's vrijwel ongewijzigd uit de circa vijftien model-noodverordeningen overgenomen. ${ }^{23}$ Becker en Geertjes gaan in hun bijdrage in dit themanummer van RegelMaat dieper in op de uniformiteit en differentiatie van de noodverordeningen. De gedragsvoorschriften veranderden, versoepelden ${ }^{24}$ of werden juist strenger in de loop van de tijd. Toch kan in algemene zin iets over hun inhoud worden gezegd. Ruwweg samengevat betrof het: een verbod op samenkomsten van meer dan dertig personen, een gebod om in de publieke ruimte 1,5 meter afstand te houden van personen (veilige afstand) en een verbod om op openbare plaatsen met meer dan vier personen te zijn (verboden groepsvorming). Ook was het verboden om zonder toestemming van de beheerder personen in zorginstellingen te bezoeken (bezoekverbod). Voorts gold een verbod om evenementen te organiseren, met meer dan vier personen te sporten en om gezamenlijk te zingen of schreeuwen in het openbaar of in besloten plaatsen. Tot slot moesten onderwijsinstellingen, kinderopvang, contactberoepen, horeca en een groot deel van de detailhandel verschillende keren de deuren sluiten. In de meeste gevallen betrof het gedragsvoorschriften die buiten woningen en daarbij behorende erven van kracht waren en die niet golden voor leden van een gezamenlijke huishouding. Een meer precieze aanduiding is hieronder weergegeven.

20 Kamerstukken I 2020/21, 35300 VI, AZ.

21 Zie daarover J. Esser \& G. Boogaard, '25 kapiteins, 1 vloot. Differentiatie, deconcentratie en decentralisatie in de Covid-19 noodverordeningen', NJB 2020/23, p. 1644-1651 en Kamerstukken I 2019/20, 35300 VI, AL (bijlage), Memo Veiligheidsberaad van 4 juni 2020 aan de Minister van JenV met een overzicht van afwijkingen van model-noodverordeningen.

22 Op 7 augustus 2020 werd optioneel art. 2.5a model-noodverordening opgenomen, zie www. veiligheidsberaad.nl (dossier COVID-19, archief augustus 2020). Vanaf 31 augustus werd de weinig succesvolle proef in Amsterdam en Rotterdam echter gestaakt. De mondkapjesplicht in het ov voor reizigers van 13 jaar en ouder was gebaseerd op de Wet personenvervoer 2000, zie daarover Rb. Gelderland 14 juli 2020, ECLI:NL:RBGEL:2020:3433 (Mondkapje in ov), maar later werd deze zorgplicht voor de vervoerder in het openbaar en bedrijfsmatig personenvervoer en de plicht voor reizigers buiten het ov ook in noodverordeningen geregeld (zie bijv. art. 2.7-2.8 model-noodverordening van 18 november 2020).

23 De modelverordeningen zijn niet altijd gedateerd, maar bevatten wel de datum van de ministeriële aanwijzing; echter niet n.a.v. elke aanwijzing werd een model-noodverordening gemaakt. Ik achterhaalde de volgende: de modelverordening van 16 maart n.a.v. de persconferentie van 15 maart en de modelverordeningen n.a.v. de ministeriële aanwijzingen van 24 maart, 24 april, 8 mei, 26 mei, 11 juni, 26 juni, 10 juli, 7 augustus, 20 augustus, 11 september, 18 september, 25 september, 29 september, 14 oktober, 6 november en 18 november. Partiële overzichten zijn te vinden in: de bijlagen bij Kamerstukken I 2019/20, 35300 VI, AK (overzicht maart-12 juni) en de bijlagen bij Kamerstukken I 2020/21, 35300 VI, AZ (augustus-november). De vele concreet uitgevaardigde noodverordeningen zijn gepubliceerd op de sites van de veiligheidsregio's en op www.overheid.nl/ zoekresultaat/lokale_wet_en_regelgeving_uitgeb/2/10/lijst/samenwerkingsorganen. Versoepelingen met name vanaf juli en aanscherping vanaf 14 oktober. 


\section{Gerelateerd aan de model-noodverordeningen betrof het meer gedetail- leerd de volgende verboden:}

- Een verbod op samenkomsten van meer dan 30 personen. Daarbij werden onder meer uitgezonderd: Wet openbare manifestaties (Wom)-samenkomsten, artikel 6, eerste lid, Gw-bijeenkomsten, verkiezingen, vergaderingen van decentrale ambten en de Staten-Generaal, woningen, zorginstellingen, hotels en openbaar vervoer. De onderwijsinstellingen zijn verschillende periodes gesloten en/of beperkt (1,5 meter afstand!) open geweest. Gedurende de zomerperiode gold voor onder meer uitvaarten een versoepeling en mochten 100 personen aanwezig zijn. Ook was het toen toegestaan om in de buitenlucht samenkomsten tot maximaal 250 personen te organiseren. De verplichting om 1,5 meter afstand te houden was hierbij van toepassing (art. 2.1 model-noodverordening). ${ }^{25}$

- Een gebod om in de publieke ruimte (ook bij de samenkomsten) te allen tijde 1,5 meter afstand tot elkaar te houden, tenzij men deel uitmaakte van een gezamenlijke huishouding. ${ }^{26}$ Belangrijke andere uitzonderingen op dit verbod: het gold niet voor kinderen tot 12 jaar, het voortgezet onderwijs en het (openbaar) vervoer. De detailhandel, markten, bibliotheken, musea, monumenten, pretparken enzovoort dienden, voor zover ze geopend mochten zijn, de veilige onderlinge afstand te waarborgen. Dat gold zo veel mogelijk ook voor de instanties die zich met personenvervoer (voer- en vaartuigen en luchtvaart) bezighouden. Tevens bestond er in dat vervoer een zorgplicht voor en plicht tot het dragen van een mondkapje (art. 2.1 en 2.7-2.8).

- Verbod groepsvorming: een verbod om met meer dan vier (verschillende keren drie) personen in de buitenlucht of op een openbare plaats te zijn. Uitgezonderd waren onder meer leden van een gezamenlijke huishouding, kinderen tot 12 jaar, deelnemers aan toegestane samenkomsten en beroeps- en rechtszittingen (art. 2.1-2.1a).

- Sluiting van eet- en drinkgelegenheden, met uitzondering van afhaal (art. 2.3).

25 Ik gebruik hier de nummering van de modelverordening bij aanwijzing van 18 november 2020, die grosso modo overeenkomt met de nummering van de model-noodverordeningen vanaf eind juli 2020. In de maanden maart-juni was de nummering anders omdat verboden vaak gedetailleerder waren geregeld, zie bijv. de model-noodverordeningen n.a.v. de aanwijzing van 26 mei en 11 juni 2020.

26 Gezamenlijk huishouden is volgens de toelichting bij art. 2.2: de niet van tafel en bed gescheiden echtgenoot, geregistreerde partner of andere levensgezel en ouder, grootouders en kinderen, voor zover zij volgens de basisregistratie personen op hetzelfde adres woonachtig zijn. Kinderen jonger dan 12 jaar vallen buiten het verbod. De toelichtingen vermelden het niet expliciet, maar bewoners van een studentenhuis en woongemeenschappen vormen dus geen gezamenlijke huishouding (Kamerstukken I 2019/20, 35300 VI, AK, p. 14-16). Ook gezinnen met kinderen ouder dan 12 jaar waarvan de kinderen op andere huisadressen wonen, vallen buiten de definitie en dus binnen het groepsverbod, zie daarover M.A.D.W. de Jong, 'Onder druk wordt alles vloeibaar. Over noodverordeningen en het wetsvoorstel tijdelijke maatregelen covid-19 in relatie tot het recht op persoonlijke levenssfeer', TvCR 2020, afl. 4, m.n. p. 365-369. 
- Verbod op gezamenlijk zingen en schreeuwen in de publieke ruimte of in besloten plaatsen. Met inachtneming van de richtlijnen van het RIVM (onderlinge afstand enzovoort) gold dit verbod niet voor onder andere professionele zangers, Wom-manifestaties en artikel 6, eerste lid-Gw-bijeenkomsten (art. 2.4).

- Verboden gebieden en locaties: de voorzitter van de veiligheidsregio kon gebieden en locaties aanwijzen waar het verboden is om te verblijven en/of geluidsapparatuur of muziekinstrumenten aanwezig te hebben (art. 2.5-2.5a). Dit geschiedde met name in gebieden of publiek toegankelijke inrichtingen, inclusief winkels, waarin regelmatig sprake was van verboden groepsvorming en/of het onvoldoende in acht nemen van de onderlinge afstand. ${ }^{27}$

- Veel contactberoepen waren verplicht om gegevens van klanten te registreren en gedurende meerdere periodes moesten zij de deuren sluiten voor klanten (art. 2.6).

- Voor verpleegtehuizen en zorginstellingen voor ouderen gold een bezoekverbod of een verbod om zonder toestemming van de beheerder op bezoek te gaan. De toestemming moest meestal wel worden gegeven als bewoners in de stervensfase of vergelijkbare omstandigheden verkeerden, of als bezoek de beperking van de verspreiding van het virus niet in gevaar bracht (art. 2.9). ${ }^{28}$

- Vanaf het najaar was tussen 20.00 en 6.00 uur de detailhandel gesloten (met uitzondering van levensmiddelenzaken) en mocht geen alcohol verkocht, aangeboden of genuttigd worden in de publieke ruimte (art. 2.10-2.11).

- Het was, periodes van versoepeling daargelaten en jonge mensen en met name beroepssporters uitgezonderd, verboden buiten de woning of daarbij behorende erven met meer dan vier personen te sporten. Publiek bij sportwedstrijden was niet toegestaan (art. 2.12).

- Het organiseren van evenementen is meestentijds vrijwel verboden, introductieactiviteiten voor studenten zijn grotendeels verboden (art. 2.13-2.14).

Een algehele uitzondering werd gedurende de gehele periode gemaakt voor activiteiten die noodzakelijk zijn voor de voortgang van vitale processen, hulpdiensten en toezichthouders. Voorts kon de voorzitter van de veiligheidsregio ontheffing verlenen van de ge- en verboden (art. 3.1).

De toelichting van de noodverordeningen maakt duidelijk dat zowel de openbare ruimte als de voor het publiek openstaande gebouwen, locaties en daarbij behorende erven onder de voorschriften vallen. Evenementen om-

27 De talrijke aanwijzingsbesluiten zijn te raadplegen op de sites van de veiligheidsregio's en op https://decentrale.regelgeving.overheid.nl.

28 Zie over de vraag of het bezoekverbod voor private zorginstellingen ook door de overheid of door de beheerder werd opgelegd A.C. Hendriks \& P.B.C.D.F. Sasse van Ysselt, 'Gezondheidsrechtelijke aspecten van corona', TvCR 2020, afl. 3, par. 4.2 en N. Koffeman \& K. de Vries, 'Achter gesloten deuren. De bezoekregeling verpleegtehuizen en artikel 8 EVRM', NJB 2020/1717, par. 3.2. 
vatten alle voor het publiek toegankelijke verrichtingen van vermaak, uitgezonderd bijeenkomsten die onder de Wom vallen. Samenkomsten omvatten onder meer ook uitvaarten en bruiloften, al wordt voor het religieuze deel soms een minder stringent of geen (dringend geadviseerd) maximum aantal aanwezigen voorgeschreven. Woningen en daarbij behorende erven zijn uitgezonderd, waarbij wel expliciet het beleid is gevoerd dat bij excessen door middel van noodbevelen tegen feestjes in studentenhuizen, garages enzovoort kan worden opgetreden. In dat opzicht worden de verboden in de toelichting dus wel uitgebreid naar het domein van sommige woningen. ${ }^{29}$

Het ruwe, maar meer nog het gedetailleerde overzicht laat zien dat de voorschriften diep ingrijpen op fundamentele zaken zoals de familiebetrekkingen, relaties, onderwijs, bewegingsvrijheid inclusief de vrijheid om te sporten, en het recht op eigendom. De maatschappelijke en economische impact waren enorm en vrijwel elke burger werd hierdoor getroffen. Meteen rees dan ook de vraag: kan dit wel bij noodverordening worden geregeld en wie is hier nu eigenlijk politiek verantwoordelijk? ${ }^{30}$

\section{Analyse: lokale noodverordeningsbevoegdheid, regionaal uitgerold voor een landelijk probleem}

3.1 De noodverordeningsbevoegdheid, democratische controle en bestuurlijk toezicht

De noodverordeningsbevoegdheid vindt haar grondslag in artikel 176 jo. artikel 175, eerste lid, Gemw. De wetsgeschiedenis, jurisprudentie en praktijk in aanmerking genomen, betreft dit een bevoegdheid die bedoeld is voor incidentele noodsituaties die zich normaliter beperken tot het grondgebied van de gemeente. ${ }^{31}$ De burgemeester krijgt met de noodverordeningsbevoegdheid tijdelijk een zeer verstrekkende regelgevende bevoegdheid om een (dreigende) lokale noodsituatie te adresseren. Gebruik van deze bevoegdheid is alleen toegestaan als andere bevoegdheden geen oplossing bieden (subsidiariteitsbeginsel). Denk bijvoorbeeld aan de situatie dat vanwege het incidentele en/of spoedeisende karakter van een (dreigende) noodsituatie een raadsverordening niet tijdig of niet tijdig tot stand kan worden gebracht. In de meeste gevallen is een raadsverordening geen haalbare model-noodverordening van 18 november 2020.

30 Op 6 april werd een reeks kritische vragen gesteld door Kamerleden Groothuizen en Sneller, beantwoord op 18 mei 2020 door de Minister van JenV, Aanhangsel van de Handelingen II 2019/20, nr. 2804. Zie in de juridische literatuur m.n. A. Wierenga, J. Schilder \& J. Brouwer, 'Aanpak coronacrisis niet houdbaar', NJB 2020/18, p. 1317; Vink 2020; J.L.W. Broeksteeg, 'Verantwoording in tijden van corona', TvCR 2020, afl. 3, p. 248-262.

31 Uitgebreider: M.A.D.W. de Jong, 'De noodverordening: spinazie voor de burgemeester', in: R.J.N. Schlössels e.a. (red.), In de regel, Deventer: Kluwer 2012, p. 311-330; A.J. Wierenga, C. Post \& J. Koornstra, Naar handhaafbare noodbevelen en noodverordeningen, Amsterdam: Reed Business 2016; M.A.D.W. de Jong e.a., Orde in de openbare orde, Universiteit Utrecht/Radboud Universiteit Nijmegen 2017, te raadplegen via www.wodc.nl, deel I, hoofdstuk 5. 
optie omdat maatregelen nodig zijn waarmee wordt afgeweken van geldende regelgeving. Met een noodverordening mag de burgemeester dit doen, zij het dat hij niet van de Grondwet en internationaal recht mag afwijken. Mede vanwege dit ingrijpende karakter verzekert de Gemeentewet dat democratische controle en bestuurlijk toezicht mogelijk zijn op de uitoefening van deze bevoegdheid. Behalve de verantwoordingsplicht van de burgemeester aan de gemeenteraad (art. $180 \mathrm{Gemw}$ ), bepaalt de Gemeentewet dat de gemeenteraad in de eerstvolgende raadsvergadering de noodverordening moet bekrachtigen, dan wel deze kan laten vervallen (art. 176, tweede en derde lid). Tot het moment van die gemeenteraadsvergadering kan de commissaris van de koning (cdK) de werking van de voorschriften opschorten (art. 176, tweede en zesde lid, Gemw). Weigert de raad de noodverordening te bekrachtigen, dan kan de burgemeester administratief beroep bij de cdK instellen. Hangende dat beroep blijven de noodvoorschriften van kracht (art. 176, vierde en vijfde lid, Gemw). Daarnaast kan de Kroon ingrijpen en de noodverordening (zoals elke andere beslissing van het gemeentebestuur) schorsen of vernietigen wegens strijd met het recht of het algemeen belang. ${ }^{32}$ Als iedereen alert en goed gebruik maakt van deze bevoegdheden, dan waarborgt dit systeem dat vanaf de afkondiging van een noodverordening democratische controle en bestuurlijk toezicht op de burgemeester kunnen worden uitgeoefend. ${ }^{33}$

Bij de langdurige regionale opschaling zoals bij de covidcrisis gaat het voorgaande niet meer op. De regionale noodverordening raakt dan niet één van de ruim 350 gemeenten maar een of meer van de 25 veiligheidsregio's en dus navenant meer gemeenten en burgers. In die situatie wordt vervolgens de regeling van verantwoording en toezicht uit de Gemeentewet vervangen door de voorzieningen uit de Wvr en die is uit het oogpunt van democratische invloed en verantwoording bepaald zwakker. ${ }^{34}$ Samengevat komt deze erop neer dat de burgemeesters van de veiligheidsregio, uitgezonderd de voorzitter, geen directe zeggenschap over de besluitvorming toekomt, hooguit kunnen ze aanspraak maken op voorafgaand overleg met de voorzitter van de veiligheidsregio als hij besluiten neemt. Voorts kunnen ze binnen het Regionaal Beleidsteam bezwaar laten aantekenen tegen maatregelen die de voorzitter neemt. ${ }^{35}$ Een echt breekijzer is dat niet. Gemeenteraden kunnen 'hun' burgemeester vervolgens weer ter verantwoording roepen over diens inbreng of gebrek aan inbreng, maar dat zal in het algemeen weinig zinvol zijn: de inbreng is beperkt en moeilijk te achterhalen. Het betrof in de covidcrisis immers besluiten die voor een gehele regio werden genomen, het belang van één gemeente kan dan meestal maar beperkt meewegen. Daar kwam nog bij dat de beslissingen uiteindelijk vooral op landelijk niveau werden genomen, zoals ik eerder

32 Art. 132, vierde lid, Gw. jo art. 268 en 273a Gemw.

33 Voorts kan de rechter in een civiele of strafrechtelijke procedure (onrechtmatige wetgeving of overtreding noodverordening) een oordeel geven. Uitgebreider: De Jong 2012, p. 327-329.

34 Respectievelijk art. 176, derde t/m zesde lid, Gemw en art. 39, eerste lid, sub b, Wvr. De verantwoordingsplicht van de besturen van de veiligheidsregio op grond van de WGR laat ik hier buiten beschouwing nu art. 39-42 een meer specifieke regeling bevatten voor de covidcrisis.

35 Art. 39, tweede t/m vierde lid, Wvr. Doen ze dat niet dan wordt het besluit aan de burgemeester toegerekend. Zie daarover T. Cammelbeeck, 'De Tweede Kamer en de minister moeten de lokale democratie respecteren', NJB 2020/1810. 
besprak. Hoe groot is dan de verantwoordelijkheid van een gemeentebestuurder? ${ }^{36}$ Democratische verantwoording legt de voorzitter van de veiligheidsregio af door middel van een verslag aan de gemeenteraden na afloop van de crisis. Tussentijds is wel iets mogelijk: hij beantwoordt tijdens en na de crisis vragen die de raden kunnen stellen, en deze discussie kan door tussenkomst van de cdK ook worden voorgelegd aan de Minister van JenV. ${ }^{37}$ Bij de langdurige coronacrisis, waarbij alle gemeenten betrokken waren, is dit een bepaald onpraktische regeling en komt de democratische verantwoording van de voorzitter te laat. ${ }^{38}$ Voor burgers is het verantwoordingsproces niet of nauwelijks te volgen. Bestuurlijk toezicht is er onder meer in de vorm van een aanwijzingsbevoegdheid van de cdK jegens de voorzitter, ${ }^{39}$ maar de voorzitters werden in deze crisis vooral gestuurd door de aanwijzingen van de minister op grond van de Wpg. Schorsing en vernietiging van een regionale noodverordening door de Kroon is strikt genomen mogelijk (art. 36 Wet gemeenschappelijke regelingen; WGR), maar ook daarvoor geldt: het kabinet stond aan de wieg van de inhoud van de noodverordeningen! Het bestuurlijk toezicht ligt al met al vooral bij de instantie die materieel ook de regels bepaalt.

Daarenboven rijst de vraag: in hoeverre kan er door een regionaal ambt verantwoording worden afgelegd als de noodverordening inhoudelijk vooral door aanwijzingen van de minister wordt gedicteerd? Nu kan men stellen: voor die aanwijzingen verantwoordt de minister zich jegens het parlement (art. $68 \mathrm{Gw})$. Deels is dat het geval: de Tweede Kamer werd vrijwel wekelijks op de hoogte gehouden door onder meer leden van het OMT middels technische briefings en rondetafelgesprekken, gevolgd door debatten met de verantwoordelijke ministers. ${ }^{40}$ Daarnaast was er een intensieve uitwisseling van opvattingen en informatie tussen regering en Staten-Generaal door middel van briefverkeer, (commissie)overleg en debat, maar met name de Eerste Kamer was niet altijd tijdig geïnformeerd over onder meer de aanwijzingen en de noodverordeningen. ${ }^{41}$ Daarnaast versnippert in deze constructie de verantwoording: vraagstukken over de inhoud en handhaving van de noodverordeningen hebben zowel op het niveau van de gemeente als in de Kamers tot debat geleid wie in hoeverre verantwoordelijk was. ${ }^{42}$ Het voorgaande is des te pro-

36 Zie voor een meer uitgebreide en precieze analyse van de invloed van het Veiligheidsberaad en de voorzitters de bijdrage van Becker en Geertjes in dit themanummer.

37 Art. 40 Wvr.

38 Ook: Broeksteeg 2020; E. Muller e.a., Evaluatie wet veiligheidsregio's, 4 december 2020, p. 68-70, Bijlage bij brief van 4 december 2020 van de minister van JenV aan de Tweede Kamer, kenmerk 3112642. Kamerstukken I 2020/21, 35300 VI, ZA, p. 5 e.v.

39 Art. 41-42 Wvr en art. 5a-d Ambtsinstructie van de commissaris van de Koning.

40 Zie voor data, inhoud en een overzicht hiervan www.tweedekamer.nl/kamerleden-en-commissies/ commissies/volksgezondheid-welzijn-en-sport/thema-coronavirus.

41 Zo kwam de minister toezeggingen over het verstrekken van informatie over de noodverordeningen en aanwijzingen jegens de Eerste Kamer meerdere keren niet na, zie de brief van de voorzitter van de vaste commissie voor JenV van 5 oktober 2020, waarin een overzicht staat van de periode juni-oktober, Kamerstukken I 2020/21, 35300 VI, AZ, p. 3.

42 Bijv. n.a.v. een vergunning aan Tilburgse voetbalsupporters om bijeen te komen: Kamerstukken I 2020/21, 35300 VI, AZ, p. 5-6 en 16-17: de minister werd erop bevraagd, de betreffende burgemeester is tevens voorzitter van de veiligheidsregio. 
blematischer omdat de noodverordeningen met name op het punt van de vergaande grondrechtenbeperking omstreden zijn.

\subsection{De noodverordeningsbevoegdheid in relatie tot grondrechten uit de Grondwet ${ }^{43}$}

Beziet men de in paragraaf 2 weergegeven gedragsvoorschriften, dan is helder dat deze de uitoefening van een aantal grondwettelijk beschermde grondrechten aan banden leggen. In een voorlichting van de Raad van State ${ }^{44}$ en in de literatuur werd al snel vastgesteld dat vooral de voorschriften betreffende de veilige afstand, het bezoekverbod aan zorginstellingen, het verbod op samenkomsten en de verboden groepsvorming grondrechten aan banden leggen, met name het recht op persoonlijke levenssfeer (art. $10 \mathrm{Gw}$ ), ${ }^{45}$ de vrijheid van godsdienst en levensovertuiging (art. $6 \mathrm{Gw})^{46}$ en de vrijheid van vergadering en betoging. ${ }^{47}$ Kan dit bij noodverordening worden geregeld? Voorts lag de vraag op tafel of eventueel bij noodverordening bepaald mag worden dat het verbod op samenkomsten en samenzang en een eventueel mondkapjesgebod ook binnen gebedshuizen zouden mogen gelden? En in hoeverre mogen voorschriften op woningen of daarbij behorende erven van toepassing zijn?

Ik stel voorop dat mijns inziens de overheid terecht in maart 2020 de zeer ingrijpende maatregelen afkondigde. In de voorlichting van de Raad van State en in de literatuur is dat vrij algemeen onderschreven. ${ }^{48}$ Onder meer vanuit de grondwettelijke (art. $22 \mathrm{Gw}$ ) en verdragsrechtelijke positieve verplichtingen diende zij de volksgezondheid en het recht op leven te beschermen (art. 2-3 van het Europees Verdrag tot bescherming van de rechten van de mens en de fundamentele vrijheden; EVRM). De gebeurtenissen in Noord-Italië hadden laten zien dat de virusuitbraak in snel tempo tot ernstige overbelasting van de gezondheidszorg leidde en dat het aantal zieken en doden pijlsnel steeg, met hartverscheurende situaties tot gevolg. ${ }^{49}$ Ook bij een eventuele gebrekkige (grond)wettelijke basis kon de overheid,

43 Met de noodverordeningsbevoegdheid mogen verdragsrechtelijk beschermde grondrechten worden beperkt als aan de voorwaarden van de bepalingen is voldaan. Hoewel daar in relatie tot de coronacrisis ook interessante vraagstukken liggen, was het meest klemmende vraagstuk de verhouding tot de Grondwet. Ter wille van de noodzakelijke beperking van de omvang van deze bijdrage beperk ik de bespreking tot de verhouding tot de Grondwet.

44 De eerdergenoemde voorlichting van de Afdeling advisering RvS van 25 mei 2020, 'Voorlichting over grondwettelijke aspecten van (voor)genomen crisismaatregelen', te raadplegen op www. raadvanstate.nl.

45 Zie behalve de voorlichting van de Afdeling advisering RvS, Hendriks \& Sasse van Ysselt 2020, p. 262-282; Koffeman \& De Vries 2020, p. 1936-1947; De Jong 2020, p. 364-381.

46 Zie behalve de voorlichting van de Afdeling advisering RvS, A. Vleugel, 'De beperking van de godsdienstvrijheid door middel van "corona-noodverordeningen” zijn rechtmatig', TvCR 2020, afl. 3, p. 290-300 en Vleugel 2021.

47 Voor de vergadervrijheid van o.m. volksvertegenwoordigingen en bestuursorganen maken de noodverordeningen een uitzondering en is specifieke wetgeving tot stand gebracht. Zie over de beperking van deze grondrechten door covidmaatregelen wederom de eerdergenoemde voorlichting van de Afdeling advisering RvS en B. Roorda \& J.G. Brouwer, 'De vrijheid om te demonstreren in Coronatijd'. Coronacrisis en het recht, deel 11, te raadplegen op www.openbareorderecht.nl.

48 Zie de bronnen in voetnoten 44-47.

49 Zie bijv. J. van der Ploeg, 'Corona-nabestaanden Bergamo doen aangifte tegen de staat: waarom ging het juist hier zo mis?', de Volkskrant 12 juli 2020. 
mogelijkerwijs met een beroep op (ongeschreven) subjectief noodrecht, in de eerste maanden de noodverordeningen uitvaardigen. Snelle vervanging van deze eerste noodverordeningen door formele wetgeving is echter noodzakelijk om twee redenen. De noodverordeningsbevoegdheid biedt onvoldoende basis voor een deel van de hiervoor omschreven gedragsvoorschriften en bovendien is deze niet in het leven geroepen voor langdurige, regionale of landelijke maatregelen; behalve de regels die gelden voor beperking van grondwettelijk beschermde grondrechten, schieten dan ook de waarborgen met betrekking tot democratische legitimatie, verantwoording en toezicht daarvoor tekort. Ik besprak dat laatste hiervoor al.

Voor wat betreft het punt van de grondrechten kan mijns inziens bij noodverordening slechts in beperkte mate inbreuk worden gemaakt op de grondrechten van de godsdienst-, vergader-, betogings- en uitingsvrijheid, en alleen voor zover deze geregeld zijn in artikel 6, tweede lid, 9, tweede lid, 7, derde lid, Gw. Voor het recht op persoonlijke levenssfeer (art. $10 \mathrm{Gw}$ ) is met enige creativiteit uit de grondwetsgeschiedenis hooguit voor korte tijd een grondslag voor beperking te herleiden en voor een eventuele aantasting van artikel 6 , eerste lid, Gw ontbreekt deze grondslag geheel. Ik licht dit toe en moet daarvoor kort ingaan op de parlementaire geschiedenis van artikel 176 Gemw.

De belangrijkste waarborg van het beperkingssysteem van de Grondwet is de eis dat de formele wetgever bepaalt of een grondrecht beperkt mag worden, en zo ja, onder welke voorwaarden. Voor zover de wetgever deze bevoegdheid aan de burgemeester delegeert, dient dit niet 'blanco' te gebeuren, maar moet hij aangegeven onder welke voorwaarden een grondrecht mag worden beperkt. Dat is niet gebeurd in artikel 176 Gemw. De wet rept niet over grondrechtenbeperking door de noodverordeningsbevoegdheid. Zij stelt slechts (of: juist) dat de burgemeester bij het toepassen van die bevoegdheid niet van de Grondwet mag afwijken. Bij de behandeling van de Gemeentewet ontstond discussie over de vraag of dat terecht was: Kamerleden vreesden dat de burgemeester te weinig kon uitrichten bij grote ordeverstoringen rond samenkomsten, betogingen en vergaderingen als hij geen grondrechten mocht beperken. Vervolgens is voor die situaties naar de Grondwet gekeken om te achterhalen of de burgemeester voldoende bevoegdheden had om de genoemde ordeverstoringen aan te pakken. ${ }^{50}$ In beginsel zou de burgemeester met de specifieke beperkingsbevoegdheden uit de Wom de meeste (dreigende) ordeverstoringen kunnen adresseren. Voor de gevallen waarin dat niet mogelijk is, werd door de regering aangegeven - en door het parlement geaccepteerd - dat de noodverordeningsbevoegdheid onder voorwaarden als een wettelijke toepassing van gedelegeerde beperkingsbevoegdheid mag worden beschouwd ten aanzien van artikel 6, tweede lid, Gw (godsdienst en levensovertuiging) en artikel 9, tweede lid, $\mathrm{Gw}$ (vergadering en betoging). Voor dat oordeel was van belang dat de genoemde

50 Zie voor de parlementaire geschiedenis m.n. Kamerstukken II 1985/86, 19403, nr. 3, p. 150, Kamerstukken II 1988/89, 19403, nr. 10, p. 97-101 en Handelingen I 11 februari 1992, nr. 17, p. 566-567, 581-582 en 588. Zie voor een meer uitgebreide bespreking Vleugel 2020, p. 291-294; De Jong 2020, p. 369-371, de eerdergenoemde voorlichting van de Afdeling advisering RvS, p. 10-21 en de in die publicaties genoemde andere literatuur. 
grondwetsbepalingen delegatie toestaan en dat de doelcriteria uit die bepalingen (bescherming gezondheid, belang verkeer en bestrijding wanordelijkheden) overeenkomen met het doel waarmee de burgemeester in de meeste gevallen noodverordeningen afkondigt. Ook - maar minder relevant in relatie tot de covidcrisis werd aangegeven dat een noodmaatregel ter bestrijding van noodsituaties rond uitingen in de openbare ruimte was toegestaan, met inachtneming van de criteria uit de verspreidingsjurisprudentie. ${ }^{51}$ Over de bescherming van de persoonlijke levenssfeer hebben regering en parlement niet gesproken. Datzelfde geldt voor de vrijheid van godsdienst en van levensovertuiging binnen gebouwen en besloten plaatsen. Naar mijn oordeel moet daarom worden aangenomen dat de burgemeester die grondrechten op grond van artikel $176 \mathrm{Gemw}$ in beginsel niet mag beperken.

Past men deze uitleg van de noodverordeningsbevoegdheid toe op de gedragsvoorschriften die tijdens de covidcrisis zijn afgekondigd, dan moet voor de beoordeling van hun rechtmatigheid onderscheid gemaakt worden tussen enerzijds de voorschriften die de godsdienst-, betogings- en vergadervrijheid beperken en anderzijds de voorschriften die de persoonlijke levenssfeer beperken. Voorts moet bij de voorschriften die de godsdienst- en betogings- en vergadervrijheid beperken, een onderscheid worden gemaakt tussen voorschriften die het eerste en/of het tweede lid van artikel 6 en 9 raken. In geval van de uitoefening van de vrijheid van godsdienst en levensovertuiging en vergadering en betoging is uit de parlementaire geschiedenis van de Gemeentewet af te leiden dat beperking bij noodverordening in het belang van de gezondheid in te passen is in het grondwettelijke beperkingssysteem. Verboden en beperkingen kunnen bij noodverordening worden opgelegd voor zover de Wom geen uitkomst biedt. Dat het een en ander niet expliciet in artikel 176 Gemw is geregeld, is, zoals ik elders constateerde, in strijd met de letter van de Grondwet, maar gezien hetgeen is besproken door regering en parlement bij de totstandkoming van de Gemeentewet niet met de geest. ${ }^{52}$ Het vaststellen van gedragsnormen in gebedshuizen, zoals beperking van de groepsgrootte tot dertig personen of een verbod tot samenzang, acht ik niet mogelijk. Artikel 6, eerste lid, $\mathrm{Gw}$ legt die bevoegdheid exclusief bij de formele wetgever. ${ }^{53}$ Ook de Raad van State constateerde dit, maar meende dat voor korte tijd dergelijke beperkingen toch mogelijk waren met een beroep op de redelijke uitleg van het grondrecht. De Raad redeneerde dat gedurende de ernstige coronacrisis het grondrecht niet zo ver reikt dat men met meer dan dertig personen bijeen kan komen, temeer omdat - ondanks zo'n beperking - uitzendingen en livestreams van kerkdiensten mogelijk

51 M.n. HR 28 november 1950, ECLI:NL:HR:1950:1, NJ 1951/137 (APV Tilburg), HR 17 maart 1953, ECLI:NL:HR:1953:AG1989, NJ 1953/389 (Nuth) en HR 2 oktober 1979, ECLI:NL:HR:1979: AA6082, NJ 1980/105 (Tilburg). De redenering is terug te zien in: ARRvS 30 december 1993, ECLI: NL:RVS:1993:AN3571, AB 1994/242 (Verbod persconferentie).

52 De Jong 2020, p. 371.

53 Ook de Wom biedt daarvoor geen grondslag. Art. 8 Wom maakt weliswaar ingrijpen op besloten plaatsen mogelijk, maar slechts in zeer beperkte mate. 
blijven en de uitoefening van het grondrecht dus niet volledig wordt verboden. ${ }^{54}$ Hierbij wordt mijns inziens over het hoofd gezien dat het bijwonen van een gebedsdienst, zeker in onzekere tijden, tot de kern van de godsdienstvrijheid behoort. Een redelijke uitleg van het grondrecht laat deze gedraging dan ook binnen de reikwijdte van het grondrecht vallen. De reikwijdte van een grondrecht krimpt niet door uitzonderlijke omstandigheden. Wel is helder dat onder deze omstandigheden wellicht grotere beperkingen geaccepteerd moeten worden in het belang van de volksgezondheid. Uit dat oogpunt zou het samenkomen binnen gebouwen beperkt of zelfs verboden kunnen worden, maar een dergelijk voorschrift moet, zoals hiervoor is besproken, gezien artikel 6, eerste lid, Gw en het beperkingssysteem van de Grondwet van de formele wetgever komen.

Voor het recht op privacy geldt deels, maar niet helemaal hetzelfde..$^{55}$ De wetsgeschiedenis van de noodverordeningsbevoegdheid biedt geen houvast voor de stelling dat beperking is toegestaan. Bovendien is het grondrecht zelf vaag: er valt een bonte reeks aan gedragingen en situaties onder. Een gedragsvoorschrift zoals een bezoekverbod aan zorginstellingen heeft in veel gevallen een hele andere lading dan het gebod in de publieke ruimte een mondkapje te dragen. Precies om die reden is een nadere duiding door de wetgever nodig. Artikel 10, eerste lid, Gw maakt weliswaar delegatie mogelijk, maar kadert dat verder niet in met doelvoorschriften. Uit niets kan worden afgeleid dat beperking bij noodverordening is toegestaan en welke voorwaarden dan gelden. Hooguit kan men ten aanzien van artikel $10 \mathrm{Gw}$ in de grondwetsgeschiedenis een aanknopingspunt vinden in combinatie met de genoemde positieve verplichting om de volksgezondheid en het recht op leven te beschermen. De regering heeft bij de grondwetsherziening aangegeven dat het mogelijk is dat proportionele beperkingen die niet tot de grondwettelijke beperkingsclausule herleidbaar zijn, onder bepaalde voorwaarden rechtmatig kunnen zijn. Dat kan het geval zijn als de beperkende maatregelen algemeen aanvaard worden of als intrekking van die maatregelen 'in flagrante strijd' zou zijn met wat in het algemeen als redelijk wordt gezien. ${ }^{56}$ Voor de beperkingen van de persoonlijke levenssfeer buiten de woning in de eerste fase van de bestrijding van een virusuitbraak is dit verdedigbaar: argumenten ontleen ik aan de positieve verplichtingen en het acute gevaar van de covidcrisis, in combinatie met de sinds 1983 sterk toegenomen acceptatie dat ook een bestuurder als de burgemeester het recht op persoonlijke levenssfeer kan beperken als de openbare orde, gezondheid of veiligheid daartoe noodzaakt. ${ }^{57}$ Voor zeer ingrijpende inbreuken, bijvoorbeeld de gedragsvoorschriften ook van toepassing verklaren in woningen, gaat het voorgaande niet op. Evenmin rechtvaardigt deze redenering dat voor langere tijd de gedragsvoor-

54 Voorlichting van de Afdeling advisering RvS, m.n. p. 18. Vleugel 2020 volgt de RvS hierin en benadrukt in Vleugel 2021 vooral het belang van de bijeenkomsten en het feit dat de organisaties via overleg zelf binnen de gebouwen de richtlijnen van het RIVM respecteerden en handhaafden.

55 Uitgebreider zette ik dat uiteen in De Jong 2020, p. 371-374 en 379-381.

56 Kamerstukken II 1975/76, 13872, nr. 3, p. 21-22 en M.C. Burkens, Algemene leerstukken van grondrechten naar Nederlands constitutioneel recht, Zwolle: W.E.J. Tjeenk Willink 1989, p. 113-138.

57 Zie bijv. de sindsdien ingevoerde bevoegdheden om een tijdelijk huisverbod (Wet tijdelijk huisverbod), preventief fouilleren en cameratoezicht mogelijk te maken, woningen te sluiten en gebiedsen groepsverboden op te leggen (Gemeentewet). 
schriften die het recht op persoonlijke levenssfeer beperken op noodverordeningen worden gebaseerd. Dan is immers niet meer verdedigbaar dat die beperkende maatregelen algemeen aanvaard worden: buiten de directe noodsituatie zal de legitimiteit van de maatregelen snel afbrokkelen als zij niet berusten op een expliciete, genoegzame wettelijke grondslag. Bovendien wordt voorbijgegaan aan de kern van de grondwettelijke grondrechtenbescherming.

\section{De periode vanaf 1 december: wet en ministeriële regeling}

In veel opzichten was het derhalve vanzelfsprekend dat vanaf mei al aan aanpassing van de Wpg werd gewerkt ter vervanging van de noodverordeningen. Het oorspronkelijke wetsvoorstel lag in juni bij de Raad van State, maar is ingrijpend gewijzigd, mede op advies van de Raad van State. ${ }^{58}$ Desalniettemin nam de parlementaire behandeling maanden in beslag. De wet trad uiteindelijk op 1 december in werking en verving vanaf dat moment de regionale noodverordeningen.

De Twm covid- $19^{59}$ breidt de Wpg tijdelijk uit met een hoofdstuk Va. De wet beoogt de belangrijkste kritiekpunten weg te nemen en in een flexibele regeling te voorzien, zodat bij de snel wisselende omstandigheden in geval van een virusbestrijding efficiënt opgetreden kan worden. Voorts moet de wet de noodzakelijke grondslag voor grondrechtenbeperking geven en de democratische controle op de maatregelen versterken. ${ }^{60}$ Voor wat betreft het laatste punt: om directe democratische verantwoording mogelijk te maken is primair gekozen voor landelijke regelgeving, die vooral op gemeentelijk niveau wordt uitgewerkt. Daar krijgt met name de burgemeester bevoegdheden om ontheffingen te verlenen en plaatsen aan te wijzen waar covidmaatregelen gelden. ${ }^{61}$ Hoe dit in de praktijk werkt, is vooralsnog niet duidelijk: door de gedeeltelijke en/of verzwaarde lockdown is er tot dusver nauwelijks ruimte geweest voor ontheffingen.

Gelet op hetgeen in paragraaf 3 is besproken, acht ik de keuze voor twee bestuurslagen (centraal-lokaal), waar tevens directe democratische controle plaats kan vinden, een vooruitgang. Op landelijk niveau is in democratische inbreng voorzien, onder meer doordat een en ander nu bij wet is geregeld. Voor zover uitwerking bij ministeriële regeling geschiedt, voorziet de wet in een instemmingsrecht voor de Tweede Kamer en een verplichting om de ministeriële regeling vooraf aan beide Kamers voor te leggen. ${ }^{62}$ De regeling van artikel 58c, tweede lid, Twm covid-19 is mijns inziens ongelukkig: het van rechtswege laten vervallen van spoedeisende

58 Zie voor een overzicht van de wijzigingen m.n. het advies van de RvS, Kamerstukken II 2019/20, 35526, nr. 4, en de MvT, Kamerstukken II 2019/20, 35526, nr. 3, p. 48-72. Zie voorts De Jong 2020, p. 374-375.

59 Wet van 28 oktober 2020, houdende Tijdelijke bepalingen in verband met maatregelen ter bestrijding van de epidemie van covid-19 voor de langere termijn (Tijdelijke wet maatregelen covid-19), Stb. 2020, 441. Zie daarover Kamerstuk 35526.

60 Kamerstukken II 2019/20, 35526, nr. 3, p. 7-10.

61 Art. 58d, derde lid, en 58e Twm covid-19. Opschaling naar de voorzitter is nog wel mogelijk: art. 58d, eerste en tweede lid, Twm covid-19.

62 Art. 58c Wpg. 
maatregelen in een crisis kan funest uitpakken voor de crisisbestrijding en voor het vertrouwen in de crisisbestrijding; de overheid moet immers optreden, er moet meestal direct een alternatief zijn als een regeling vervalt. Cammelbeeck gaat in zijn bijdrage in dit themanummer dieper op dit vraagstuk in.

Beperking van grondrechten door middel van gedragsvoorschriften (groepsverbod, veilige afstand, samenkomstverbod enzovoort) wordt nu in zoverre door de wet zelf geregeld dat daarin de gedragsvoorschriften in algemene termen worden geregeld. ${ }^{63}$ De wet beperkt de reikwijdte van de in hoofdstuk Va gegeven bevoegdheden uitdrukkelijk tot bestrijding van de virusuitbraak. Voorts formuleert de wet de eis dat bij uitoefening van de bevoegdheden van hoofdstuk Va de uitgangspunten van de democratische rechtsstaat in acht worden genomen. Daarnaast is ook bepaald dat grondrechten zo min mogelijk worden beperkt en voor zover beperking nodig is, moet deze evenredig zijn. ${ }^{64}$ Dat kan een vage norm zijn, zij dwingt wel tot een expliciete verantwoording. De Minister van VWS bepaalt, samen met de ministers die het aangaat (in de praktijk de Ministers van JenV en Binnenlandse Zaken en Koninkrijksrelaties; BZK), bij ministeriële regeling op welke (categorieën) locaties, plaatsen, evenementen enzovoort de maatregelen van toepassing zijn. Deze omvangrijke ministeriële regeling is inmiddels frequent aangepast om onder meer de lockdown te regelen die vanaf 15 december 2020 van kracht is en die vanaf eind april 2021 langzaam afgebouwd wordt. ${ }^{65}$ Het concreet bepalen wat een veilige afstand is, geschiedt bij amvb. ${ }^{66}$ De regeling van gedragsvoorschriften in de Wpg is in beginsel uitputtend, ${ }^{67}$ maar mocht deze niet voldoende zijn, dan kan de minister in geval van acute omstandigheden met spoed een regeling afkondigen. ${ }^{68}$ De noodverordening als instrument om de covidcrisis te bestrijden is daarmee uit beeld verdwenen. ${ }^{69}$ Een afzonderlijke vermelding verdient de avondklok, ofwel het verbod om van 21.00 tot 4.30 uur in de open lucht te vertoeven. Dit verbod gold vanaf 23 januari 2021 en was aanvankelijk gebaseerd op artikel 8 van de Wet buitenge-

63 Art. 58f e.v. Wpg.

64 Art. 58b Wpg.

65 Regeling van de Ministers van VWS, van JenV en van BZK van 19 november 2020, kenmerk 1784401-214492-WJZ, houdende tijdelijke bepalingen voor het Europese deel van Nederland in verband met maatregelen ter bestrijding van de epidemie van covid-19 (Tijdelijke regeling maatregelen covid-19), Stcrt. 2020, 62301, tot dusver vanwege uitbreiding, verzwaring en versoepeling van de maatregelen veelvuldig gewijzigd. De BES-eilanden kennen elk afzonderlijke regelingen.

66 Zie art. 58c, eerste lid, en 58f Wpg en Besluit van 13 november 2020, houdende vaststelling van de veilige afstand, bedoeld in artikel 58f, tweede lid, van de Wet publieke gezondheid (Tijdelijk besluit veilige afstand), Stb. 2020, 474.

67 De VNG acht het niet uitgesloten dat bijv. bij evenementen de gemeenteraad in de APV nog aanvullende regels opneemt om te waarborgen dat deelnemers de coronamaatregelen in acht nemen, zie VNG \& Pels Rijcken, Handreiking Tijdelijke wet maatregelen covid-19 voor gemeenten, Den Haag, 16 november 2020, p. 9.

68 Art. 58c, derde lid, Wpg.

69 Zie art. 58d, derde lid, Wpg. 
wone bevoegdheden burgerlijk gezag (Wbbbg). ${ }^{70}$ Vanaf 22 februari kreeg de avondklok een grondslag in de Wpg. ${ }^{71}$ Evenals bij de meeste andere maatregelen kan bij ministeriële regeling de avondklok in concreto worden geregeld en uitgewerkt. Wel gold voor deze ministeriële regeling dat deze na uiterlijk drie weken zou vervallen, tenzij deze verlengd zou worden. Dat is uiteindelijk tot 29 april 2021 het geval geweest. $^{72}$

Op het punt van de grondrechtenbeperking zijn de meest knellende punten die in paragraaf 3 aan bod kwamen, verholpen. Voor maatregelen binnen woningen en bijvoorbeeld gebedshuizen is geen grondslag opgenomen. Wet en toelichting geven aan dat de gedragsvoorschriften daar niet gelden. In de kern is voor burgers duidelijk welke maatregelen getroffen kunnen worden. Enerzijds is de regeling beperkter dan de noodverordeningen: personen die op hetzelfde adres wonen, worden nu bijvoorbeeld als een gezamenlijke huishouding aangemerkt, anderzijds is de wet uitgebreid met de avondklok en de mogelijkheid van een mondkapjesplicht. De wetgever maakt hier ruim gebruik van de mogelijkheid om te delegeren, maar kadert die delegatie onder meer in artikel 58b Wpg duidelijk in. Aan delegatie valt bovendien mijns inziens niet te ontkomen: de praktijk heeft laten zien dat frequente wijzigingen van de regelgeving noodzakelijk zijn omdat bij een virusuitbraak de omstandigheden snel kunnen veranderen. En niet te vergeten omdat het ook essentieel is dat beperkingen zo snel mogelijk verminderd worden als de omstandigheden dat toelaten.

\section{Conclusie}

Wat leert het voorgaande? Ik vat dit samen en betrek daarbij ook de bijdragen van Cammelbeeck en Becker en Geertjes. Allereerst concludeer ik dat bestrijding van een grote virusuitbraak via regionale noodverordeningen niet wenselijk is en uit het oogpunt van grondrechtenbescherming in de toekomst ook niet meer rechtmatig is als vergelijkbare gedragsvoorschriften nodig zijn als bij de COVID-19-crisis. Niet wenselijk omdat deze aanpak leidt tot versnipperde en deels gebrekkige democratische controle en ontoereikend bestuurlijk toezicht. Voorts creëert dit omslachtige, tijdrovende en voor de burgers en gemeenteraden weinig inzichtelijke processen en regelgeving. De oorzaak van dit alles ligt in het gegeven dat voor een nationaal probleem de bevoegdheid op regionaal niveau wordt gezocht. Dat is onlogisch. De regio wordt immers, nu het een landelijk probleem is, zeer gedetailleerd vanaf centraal niveau aangestuurd. Ondanks die centrale aansturing is de regelge-

70 Het verbod werd uitgewerkt in een ministeriële regeling (Regeling van de Minister van JenV van 22 januari 2021, nr. 3192465, tot instelling van een landelijke avondklok ter bestrijding van de epidemie van covid-19 (Tijdelijke regeling landelijke avondklok covid-19), Stcrt. 2021, 4191. Op 22 februari 2021 is art. 8 Wbbbg bij KB buiten werking gesteld (Stb. 2021, 86) en het wetsvoorstel Voortduringswet art. 8 Wbbbg (Kamerstuk 35722) ingetrokken. De ministeriële regeling bleef van kracht en is nadien gewijzigd om de avondklok tot eind april van kracht te laten zijn (zie o.a. Stcrt. 2021, 7378).

71 Art. 58j, eerste lid, sub f, jo. art. 58c, zevende lid, Wpg.

72 De tijdslimiet is het gevolg van het aannemen van het amendement-Van Dam/Groothuizen (Kamerstukken II 2020/21, 35732, nr. 9). 
ving regionaal en daardoor raakt het overzicht al snel zoek: in een periode van negen maanden zijn meer dan driehonderd noodverordeningen afgekondigd, in 25 regio's. Daarop is niet of nauwelijks effectieve (democratische) controle mogelijk. Becker en Geertjes laten zien hoe moeilijk het is om zicht te krijgen op die regelgeving en besluitvormingsprocedures. Daarmee zijn we er nog niet, want de uitvoering geschiedt vervolgens niet op regionaal, maar vooral op lokaal niveau. Conclusie: hier is een drietrapsraket gecreëerd die wellicht voor een korte incidentele crisis voldoet, maar niet voor een langdurige, landelijke crisis. Centralisering is dan noodzakelijk.

Zou het dan beter zijn om artikel 53 Wvr in te zetten? Cammelbeeck analyseert deze procedure, waarbij de bevoegdheden van de burgemeester naar de Minister van JenV worden overgeheveld. Ik acht dat niet wenselijk in geval van een crisis zoals we die het afgelopen jaar hadden. Aan die constructie kleeft immers dan nog steeds het bezwaar dat voor een potentieel langdurig en landelijk probleem de noodverordeningsbevoegdheid wordt gebruikt en die is daar in meerdere opzichten ongeschikt voor: voor langdurige en grootschalige inperking van (grond)rechten door welk ambt dan ook is deze bevoegdheid niet bedoeld en de wetgever heeft haar ook niet met het oog daarop van waarborgen en beperkingen voorzien. Bovendien gaat het hier in de eerste plaats om gedragsvoorschriften die vanuit het perspectief van bescherming van de volksgezondheid worden afgekondigd. Regulering hoort dan ook primair bij de Minister van VWS te liggen, als ervoor gekozen wordt deze aan een minister op te dragen. Niet de Wvr moet hier het wettelijke kader zijn, maar de Wpg, aangezien deze de bestrijding van infectieziekten al regelt. Dat is bovendien wenselijk omdat de toekomstige regeling met de bestaande Wpg moet worden afgestemd. Die wet geeft immers een regeling voor de bestrijding van minder grote, of minder ernstige uitbraken.

Mijns inziens moet de Twm covid-19 een opvolger krijgen in een Wet maatregelen virusuitbraak. De wetgever moet zich daar meteen over buigen zodra de tijdelijke wet vervalt. De Nederlandse bevolking is immers meer dan een jaar geconfronteerd met een collectieve vrijheidsbeperking die voor vrijwel iedereen ongekend is, en er bestaat een zeer reële mogelijkheid dat zich in de toekomst een vergelijkbare situatie zal voordoen. Ten eerste is het onzeker wat het effect zal zijn van de verschillende vaccins en virusmutaties op langere termijn. Daarnaast kunnen ook andere virussen, waarvoor geen vaccin beschikbaar is, de kop opsteken. Dat noodzaakt tot wetgeving: met de huidige ervaringen kan het bij een volgende crisis niet zo zijn dat de wetgeving niet op orde is.

Het afgelopen jaar is ervaring opgedaan met de vraag welke gedragsvoorschriften noodzakelijk zijn. De wetgever is nu aan zet om de opgedane kennis te benutten en voor de toekomst een rechtsstatelijk gedegen regeling te ontwerpen. Dat is ook de plicht van de wetgever, gelet op het beperkingssysteem voor de grondrechten van de Grondwet. Inbreng van het parlement is juist hier nodig. De overheid komt immers voor moeilijke keuzes te staan en die moeten voor zover mogelijk vooraf door de wetgever worden gemaakt en, wederom voor zover mogelijk, concreet vastgelegd worden in de wet. De Twm covid-19 heeft daarin een belangrijke stap gezet 
door de grondslag te bieden voor gedragsvoorschriften zoals veilige afstand, avondklok, verboden groepsvorming en quarantaineplicht voor reizigers. ${ }^{73}$ Dergelijke voorschriften kunnen bij een virusuitbraak niet worden gemist en horen ook in de nieuwe wet. De wetgever zou daarbij ook moeten debatteren over de vraag of en in hoeverre het in uitzonderlijke situaties mogelijk gemaakt moet worden om bij virusuitbraken maatregelen te treffen die in woningen en gebedshuizen gelden. De discussie daarover deed zich nu al voor en zal bij een nieuwe uitbraak versterkt terugkeren.

Het voorgaande jaar leerde ook dat de adviezen en voorlichtingen van de Raad van State op een aantal momenten cruciaal zijn geweest voor de bescherming van de grondrechten. Ik denk met name aan de voorlichting over de grondwettelijke aspecten van de covidmaatregelen en het advies over de Twm covid-19. Ook de Eerste Kamer heeft in dat opzicht een belangrijke rol gespeeld. Door een Wet maatregelen virusuitbraak vast te stellen kan ten volle van deze kennis en inbreng worden geprofiteerd. Crisisbestrijding vereist echter flexibiliteit en snelheid, zoals Cammelbeeck terecht betoogt. Concreter en gedetailleerder dan de huidige Twm covid-19 zal de wet met betrekking tot de gedragsvoorschriften in het algemeen niet kunnen en niet moeten zijn. Voor de concrete uitvoering zal vergaande delegatie aan de regering of aan de minister noodzakelijk zijn. Voor de meest verstrekkende maatregelen (woningen, verpleegtehuizen, gebedshuizen, avondklok) zou eventueel wel aan regulering bij amvb kunnen worden gedacht, zodat altijd advies van de Raad van State ingewonnen wordt. Veel trager dan de ministeriële regeling in de huidige tijdelijke wet zal dit niet zijn: artikel 58c Twm covid-19 vereist immers ook al overleg met andere ministers en overeenstemming in de ministerraad en de Raad van State bleek tijdens de covidcrisis snel te adviseren.

Tot slot. De maatregelen hebben in hoge mate het karakter van staatsnoodrecht: de gevolgen voor het maatschappelijke en economische leven waren ongekend groot en strekken veel verder dan de overige bepalingen van de Wpg. Het lijkt me dan ook logisch dat deze wet als apart hoofdstuk wordt toegevoegd aan de Wpg, maar dat dit niet continu in werking is, maar binnen het kader van het staatsnoodrecht in werking kan worden gesteld door de regering. Hopelijk is Nederland dan binnen afzienbare tijd met het oog op een volgende virusuitbraak goed voorbereid. 